RESIDENT

\& FELLOW

SECTION

Section Editor

Mitchell S.V. Elkind,

MD, MS

G. Solé, MD

F. Perez, MD

X. Ferrer, MD

Address correspondence and reprint requests to Dr. Guilhem Solé, Centre de Référence des

Maladies Neuromusculaires, Pôle Neurosciences Cliniques, $\mathrm{CHU}$ de Bordeaux, Avenue de Magellan, 33604 Pessac cedex, France

guilhem.sole@chu-bordeaux.fr

\section{Teaching NeuroImages: \\ Reversible ectropion in myasthenia gravis}

Figure 1 Asymmetric ectropion due to weakness of orbicularis oculi before neostigmine

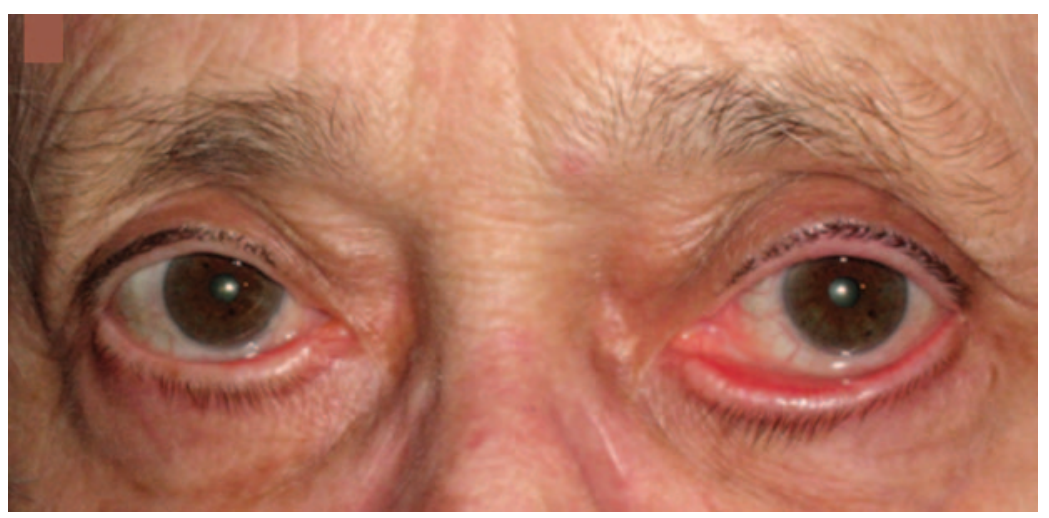

A 77-year-old woman was admitted with 1 month of progressive generalized weakness, camptocormia, dysarthria, dysphagia, and transient ectropion (figure 1). These symptoms and signs worsened after exercise. Repetitive nerve stimulation showed a decremental response $(-32 \%$ for the nasalis and $-54 \%$ for the deltoid), and serum acetylcholine receptor antibodies were positive, leading to the diagnosis of myasthenia gravis. Subcutaneous injection of 0.25 mg neostigmine improved signs consistently and ectropion disappeared (figure 2). This response was confirmed 1 month later after treatment with 300 mg pyridostigmine daily. Ectropion can be a sign of facial weakness in myasthenia gravis. ${ }^{1}$

\section{REFERENCE}

1. Cohen MM, Lessell S. Retraction of the lower eyelid. Neurology 1979;29:386-389.

Figure 2 Dramatic improvement after injection of $0.25 \mathrm{mg}$ of neostigmine

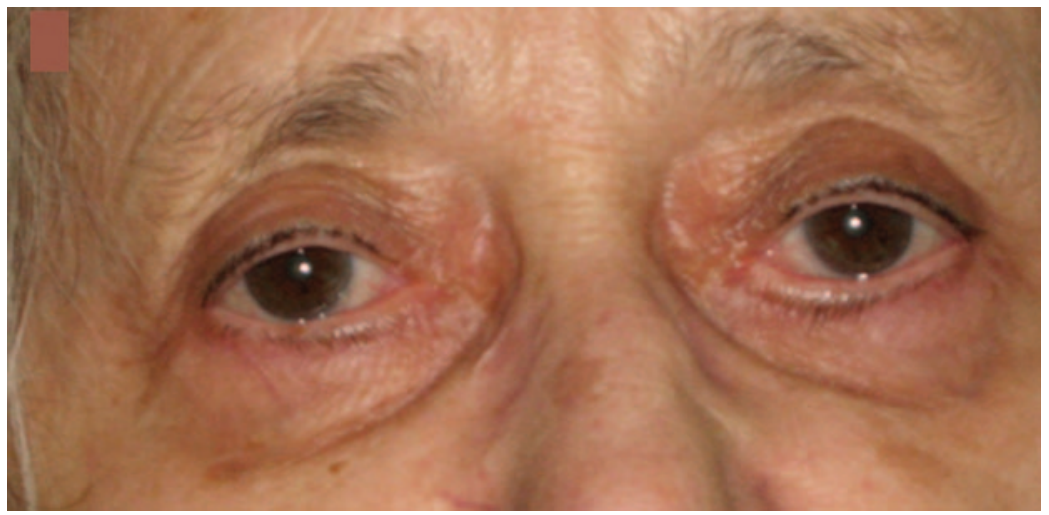

Created with Photoshop elements.

From the Centre de Référence des Maladies Neuromusculaires, Pôle Neurosciences Cliniques, CHU de Bordeaux, Pessac, France. Disclosure: Dr. Solé received non-industry-sponsored funding for travel. Dr. Perez received funding for travel from Novartis. Dr. Ferrer reports no disclosures. 


\title{
Neurology
}

\author{
Teaching NeuroImages: Reversible ectropion in myasthenia gravis \\ G. Solé, F. Perez and X. Ferrer \\ Neurology 2009;73; $\mathrm{e} 83$ \\ DOI 10.1212/WNL.0b013e3181bd1355
}

This information is current as of October 19, 2009

\section{Updated Information \& Services}

References

Citations

Subspecialty Collections

Permissions \& Licensing

Reprints including high resolution figures, can be found at: http://n.neurology.org/content/73/16/e83.full

This article cites 1 articles, 1 of which you can access for free at: http://n.neurology.org/content/73/16/e83.full\#ref-list-1

This article has been cited by 1 HighWire-hosted articles: http://n.neurology.org/content/73/16/e83.full\#\#otherarticles

This article, along with others on similar topics, appears in the following collection(s):

Clinical neurology examination

http://n.neurology.org/cgi/collection/clinical_neurology_examination Eyelids

http://n.neurology.org/cgi/collection/eyelids

Myasthenia

http://n.neurology.org/cgi/collection/myasthenia

Information about reproducing this article in parts (figures,tables) or in its entirety can be found online at:

http://www.neurology.org/about/about_the_journal\#permissions

Information about ordering reprints can be found online:

http://n.neurology.org/subscribers/advertise

Neurology ${ }^{\circledR}$ is the official journal of the American Academy of Neurology. Published continuously since 1951, it is now a weekly with 48 issues per year. Copyright . All rights reserved. Print ISSN: 0028-3878. Online ISSN: 1526-632X.

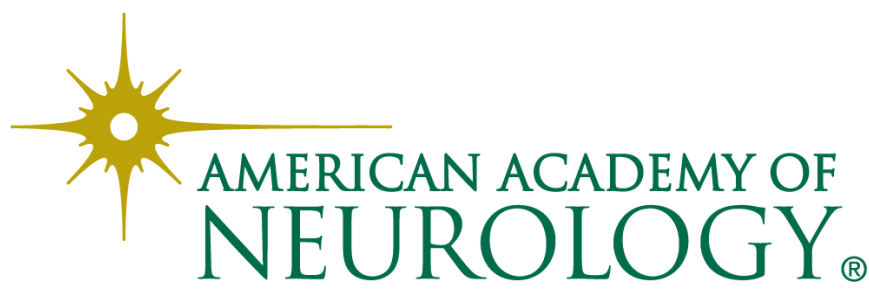

